\title{
AMPELISCID CRUSTACEANS (AMPHIPODA: GAMMARIDEA: AMPELISCIDAE) FROM THE VIETNAM SEA
}

\author{
Dang Ngoc Thanh, Le Hung Anh* \\ Institute of Ecology and Biological Resources (IEBR), VAST, *lehunganh@gmail.com
}

\begin{abstract}
Thirty-five species of the family Ampeliscidae, including 22 species of Ampelisca and 13 species of Byblis are listed for the near-shore waters of Vietnam. In the world, Ampelisca compreses more than 210 species and 83 species of Byblis. Ten species are newly recorded for the benthic Ampeliscidae fauna of the Vietnam sea, of which six new species are described, viz. Ampelisca dongnamensis; Ampelisca submisakiensis; Ampelisca talus; Ampelisca taynamensis; Ampelisca thaoae and Byblis caecus. Some remarks on their geographical distributions are presented in the paper.
\end{abstract}

Keywords: Amphipoda, Ampeliscidae, distribution, new species, taxonomy, Vietnam sea.

\section{INTRODUCTION}

Amphipods, including benthic ampeliscids, have been poorly studied in the Vietnam sea.

In some research studies $[4,13,14]$ in the coastal brackish waters of Vietnam the Ampeliscidae has not been represented at all. Data on benthic Ampeliscidae from near-shore waters of the Vietnam sea first appeared in two research works of Imbach (1967) [6] and Margulis (1968) [8]. Imbach (1967) [6] reported ten species of Ampelisca and four species of Byblis from the results of a survey carried out in Nha Trang bay (Central Vietnam), at depth range of $7-40 \mathrm{~m}$, in mud or mud - sandy sediments.

Soon after Margulis (1968) [12], reported eight species of Ampelisca and eight species of Byblis from the results of the Vietnam-Soviet cooperative study on living resources of the Vietnam in Tonkin Gulf in 1960-1961. Materials collected at depths of about $100 \mathrm{~m}$. In the above publications four species of Ampelisca and eight species of Byblis were described as new to science. According to Margulis (1968) [8], Ampeliscidae species are always the dominant group in Amphipoda benthic samples, collected at the above study sites, in species composition as well as in individual densities.

The results of our taxonomical study on a large collection of benthic Ampeliscidae from different representative localities of the near- shore waters of Vietnam at different times, has enlarged and adjusted the previous data, and added new data, to give a comprehensive knowledge on the benthic Ampeliscid fauna of the Vietnam sea.

All specimens are deposited at the Reference Collection, Institute of Ecology and Biological resources (IEBR), Vietnam Academy of Science and Technology (VAST), Hanoi.

Summarizing all existing data up to the present time, a list of 35 species belonging to the genera Ampelisca Krøyer and Byblis Boeck found in near-shore waters of Vietnam is given. The genus Ampelisca is richer in species number (22 species) than the genus Byblis (13 species). Up to now, species of genera Haploops Liljeborg and Byblisoides K.H Barnard were not yet found in the study areas (table 1).

Conforming to the zoogeographical distribution characters of the known species, it may be preliminary divided into three groups $[7,12]$ :

1. Eight species of wide distribution group, i.e. cosmopolitan or within Indo-Pacific region namely: Ampelisca cyclops Walker, 1904; A. brevicornis (Costa, 1853); A. miops K.H. Barnard, 1916; A. stenopa Schellenberg, 1925; A. zamboangae Stebbing, 1888; A. furcigera Bulycheva, 1936; Byblis kallarthra Stebling, 1886 and B. serrata Smith, 1873.

2. Twenty one species of restricted 
distribution group, in the West Pacific region, occurring in Vietnam, China, Japan: Ampelisca bocki Dahl, 1945; A. iyoensis Nagata, 1959; A. miharensis Nagata, 1959; A. misakiensis Dahl, 1944; A. alatopedunculata Ren, 2006; A. naikaienis Nagata, 1959; A. maia Imbach, 1967; A. chinensis Imbach, 1967; A. honmungensis Imbach, 1967; A. pygmaea Schellenberg, 1938; A. typlota Ren, 2006; Byblis brachyura Margulis, 1968; B. callisto Imbach, 1967; B. io Imbach, 1967; B. ferbris Imbach, 1967; B. mucronata Pirlot, 1936; B. pilosa Imbach, 1967; B. pirloti Margulis, 1968; B. plumosa Margulis, 1968; B. rhichoceros Pirlot, 1936 and B. verae Margulis, 1968.

3. Six species newly described and found only in Vietnam, including are: A. taynamensis Dang et Le; A. dongnamensis Dang et Le; A. talus Dang et Le; A. thaoae Dang et Le; A. submisakiensis Dang et Le and Byblis caecus Dang et Le.

\section{MATERIALS AND METHODS}

Materials used in this study were collected from different localities in littoral estuarine mangrove areas, coastal sea grass beds, soft bottoms, in 2-12 $\mathrm{m}$ depth. Study sites located along coastline of Vietnam, including: Deo Ngang (106 $\left.34^{\prime} 50^{\prime \prime E} \quad 17^{\circ} 54^{\prime} 70^{\prime \prime N}\right)$; Dong Hoi $\left(107^{\circ} 31.50^{\prime} \mathrm{E} 17^{\circ} 30.60^{\prime} \mathrm{N}\right)$; Con Co $\left(107^{\circ} 20.00^{\prime} \mathrm{E}\right.$ $\left.17^{\circ} 05.00^{\prime} \mathrm{N}\right)$; Thuan An $\left(107^{\circ} 38.00^{\prime} \mathrm{E}\right.$ $\left.16^{\circ} 35.30 ' \mathrm{~N}\right)$; Da Nang $\left(108^{\circ} 15.00{ }^{\prime} \mathrm{E} 16^{\circ} 11.90 ' \mathrm{~N}\right)$; Dung Quat $\left(108^{\circ} 47.60^{\prime} \mathrm{E} 15^{\circ} 28.80 \mathrm{~N}\right)$; Sa Huynh $\left(109^{\circ} 04.76^{\prime} \mathrm{E} \quad 14^{\circ} 39.70^{\prime} \mathrm{N}\right)$; Quy Nhon $\left(109^{\circ} 18.90 ' \mathrm{E} 13^{\circ} 45.40 ' \mathrm{~N}\right)$; Nghi Son-Thanh Hoa (Bac Bo Gulf); Ba Ria-Vung Tau, Ca Mau (southeastern sea part); Kien Giang, Phu Quoc Island (south-western Vietnam sea area, Gulf of Thailand).

\section{RESULTS AND DISCUSSION}

\section{Description of new species}

\section{Ampeliscidae Costa, 1857}

Ampelisca Krøyer, 1842

Ampelisca taynamensis sp. n. (Figs. 1-13)

Type material: Holotype male, $5.1 \mathrm{~mm}$,
IEBR/CA H0011, Kien Giang $\left(10^{\circ} 01.03^{\prime} \mathrm{N}\right.$, $104^{\circ} 10.14$ 'E), 28 March 2009. Paratype: IEBR/CA P0011_2 (2 females, 4.8-5.0 mm), Kien Giang ( $\left.9^{\circ} 50.19^{\prime} \mathrm{N}, 104^{\circ} 20.32^{\prime} \mathrm{E}\right), 27$ March 2009.

Type locality: Kien Giang (south-western area of the Vietnam Sea).

Etymology: Local name of the southwestern area of the Vietnam Sea (Tay Nam) where the new species was found.

Description: Male, $5.1 \mathrm{~mm}$.

Head: Head with anterodistal part produced, distal margin concave; eyes 2 pairs, in the form of distinct lenses. Antenna 1 reaching to distal end of Antenna 2 peduncle; flagellum 14- articulated; peduncular article 1 shorter than article 2 in length $(2 / 3 \mathrm{x})$. Antenna 2 reaching the end of the body length; flagellum 40-articulated; peduncular article 4 shorter than article 5. First peduncular article antenna 1 and antenna 2 armed with rows of short and rigid setae. Mandibular palp article 2 inflated, shorter than article 3.

Pereon: Gnathopod 1 with long naked basis, carpus and propodus with scattered setae on ventral margin; propodus short, 1/3 length of carpus; dactylus shorter than previous article propodus. Gnathopod 2 similar in form to gnathopod 1 but shorter; propodus more than half length of carpus; dactylus as half length of propodus, ventral margin of propodus and carpus with rows of setae. Pereopod 3 with coxa rectangular, basis cylindrical, ischium very short, merus large with row of dense setae on both lateral margins; dactylus longer than propodus. Pereopod 4 similar with pereopod 3, but coxa smaller, quadrangular in form. Pereopod 5 with round basis armed with large tooth on ventral margin and row of long setae on dorsal margin. Carpus with produced posteroventral corners; dactylus very small, with serrate appendices. Pereopod 6 similar in form to pereopod 5, but basis nearly quadrangular with very small row of setae on dorsal margin. Pereopod 7 lateral expansion of basis broad, distal margin oblique with densely setae, not reaching to ischium distal end; ischium squarish, carpus oval equal in length with propodus; dactylus stick form, ending in a sharp point. 


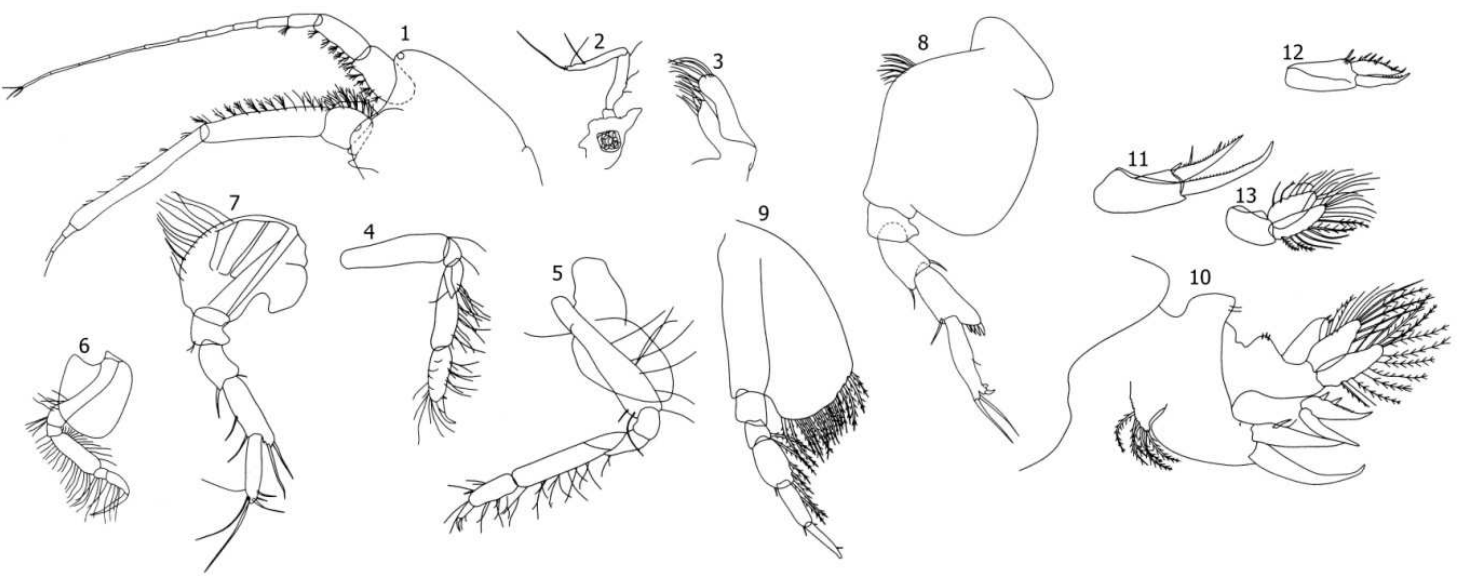

Figures 1-13. Ampelisca taynamensis sp. n.

1. Head; 2. Mandible; 3. Maxilla 2; 4-5. Gnathopod 1-2;

6-8. Pereopod 4-6; 9. Pereopod 7; 10. Urosomit; 11-13. Uropod 1-3.

Pleon: Pleon segments with dorsal carina progressively increasing to the body end. Urosomite 1 and $2+3$ with large dorsal process. Uropod 1 with smooth ramus, shorter than peduncle. Uropod 2 with serrate ramus, shorter than peduncle. Uropod 3 with broad lanceolate ramus, longer than peduncle, with row of dense plumose setae on lateral margin. Telson with naked lateral margin and distal setae.

Female: Sexual dimorphic characters: Pleon segments dorsal margin without carina. Inner sides of antenna 1, 2 peduncles smooth. Antenna 2 peduncular article 4 and 5 nearly equal in length. Flagellum shorter than antenna 1 peduncule.

Habitat: Soft bottom, 7-50 m, muddy-sand sediment.

Distribution: Kien Giang, Vung Tau (southern area of Vietnam Sea).

Remarks: This newly described species is strongly characterized by the peduncle of antenna 1 and antenna 2 , the round basis of pereopod 5, with a great tooth on the ventral margin, which distinctly separates A. taynamensis from all known species in the region. Based on the structure of pereopod 7, with the dorsally carinate pleon segments 1,2 , 3 , the dorsal process in urosomites 1 and $2+3$, A. taynamensis is near to Ampelisca misakiensis
Dahl, occurring also in Vietnam near-shore waters. However, the two species can be easily distinguished by the antenna 1 and 2 structure, the pereopod 5 basis, and the presence of two pairs of eyes in A. taynamensis.

Based on the similar structure of pereopod 7, a misakiensis species-group may be proposed, distributed in western South China Sea region, including taxonomically similar species such as A. misakiensis Dahl, A. taynamensis sp. n., A. miharaensis and A. submisakiensis sp. n. (see later).

Ampelisca dongnamensis sp. n. (Figs. 14-25)

Type material: Holotype male, $5.3 \mathrm{~mm}$, IEBR/CA H0012, Vung Tau $\left(10^{\circ} 08.91\right.$ 'N, $\left.107^{\circ} 14.65^{\prime} \mathrm{E}\right), \quad 10$ August 2000. Paratype: IEBR/CA P0012_4 (4 males, 5.1-5.3 mm), Vung Tau, 10 May 2008.

Type locality: Vung Tau.

Etymology: Local name of the south-eastern area of the Vietnam Sea (Dong Nam), where the new species was found.

Description: Male, $5.3 \mathrm{~mm}$.

Head: Head small, distal margin slightly concave, with an interantennal lobe; two eyes pairs in the form of distinct lenses installed between antennal peduncles. Antenna 1 overreaching antenna 2 peduncle; peduncular 
article 1 equal in length with article 2, article 3 short; flagellum 13-segmented. Antenna 2 reaching about to body end; flagellum 40articulate; peduncular article 4 shorter than article 5. Inner margin of peduncular articles of
Antenna 1 and Antenna 2 with rows of rigid setae. Mandibular palp with article 2 and 3 nearly similar in length. Article 2 broad, inner margin with row of setae. article 3 narrow, distal end with row of plumose setae.

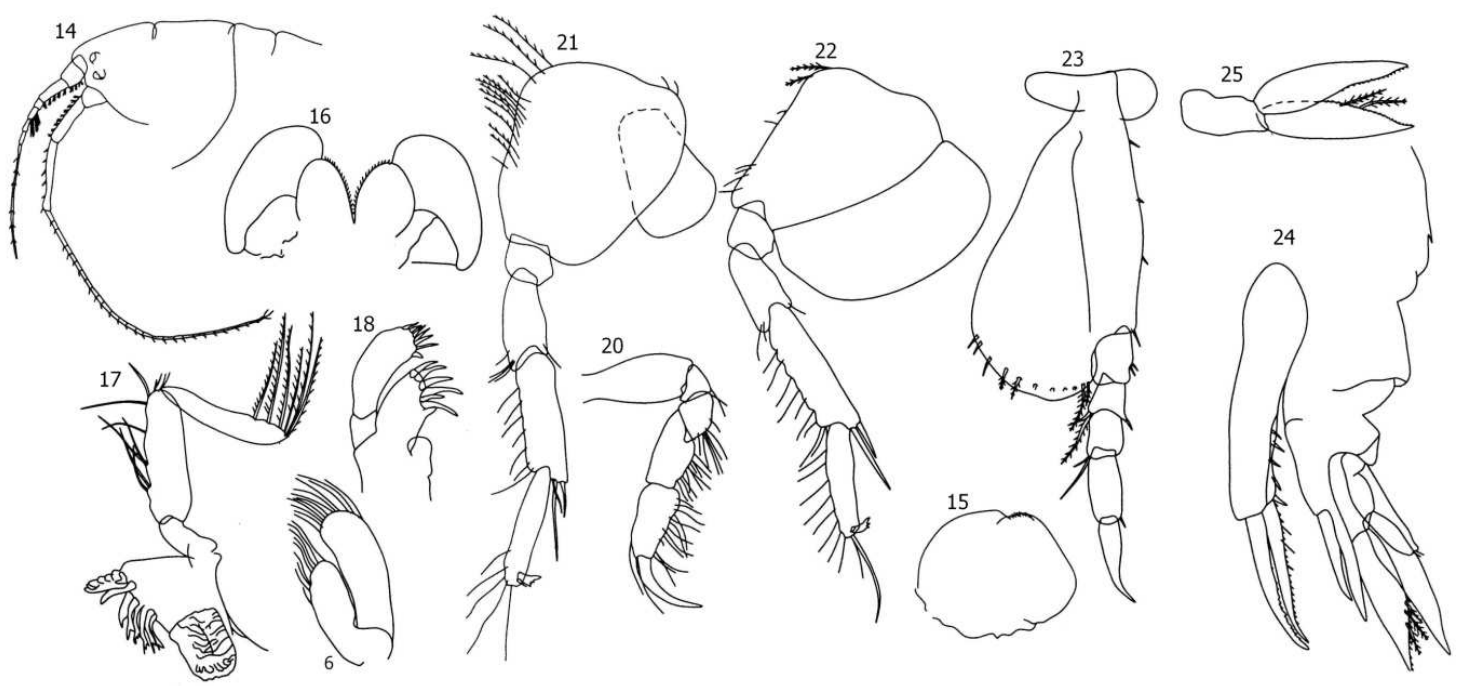

Figure 14-25. Ampelisca dongnamensis sp. n. (male)

14. Head; 15. Uper lip; 16. Lower lip; 17. Mandible; 18-19. Maxilla 1-2; 20-22. Pereopod 4-6;

23. Pereopod 7 ; 24. Urosomit, uropod; 25. Uropod 3.

Pereon: Gnathopod 1 with coxa trapezoid in form. Basis long with scattered long setae, carpus and propodus short and densely setae. Dactylus shorter than propodus. Gnathopod 2 with long rectangular coxa and long basis. Propodus as half in length of carpus, densely setae. Pereopod 3 and Pereopod 4 similar in form, with large rectangular coxa, long basis and carpus. Dactylus 2 times as long as propodus. Pereopod 5 and Pereopod 6, similar in form, basis rounded with scattered setae. Carpus with produced distal corner. Dactylus small, with serrate appendices. Pereopod 7 with lateral expansion of basis narrow, distal margin oblique; overreaching distal end of ischium, with row of scattered setae. Ischium squarish shorter than merus and carpus combined in length. Propodus rectangular, equal in length with merus and carpus combined. Dactylus longer than propodus tapering distally, ending with a curve distal portion.

Pleon: Urosomite 1-2+3 dorsal margin uneven, but without tubercles. Uropod 1 and Uropod 2 with ramus shorter than peduncle. Uropod 3 with ramus lanceolate longer than peduncle, with marginal setae. Telson long, narrow with distal setae.

Female: Unknown.

Habitat: Soft bottom 7-50 m, mud-sandy sediment.

Distribution: Vung Tau, Ca Mau (southern area of Vietnam Sea).

Remarks: In comparison with all known species in the region by the structure of pereopod 5, pereopod 6 and pereopod 7 . Ampelisca dongnamensis sp. $\mathrm{n}$. is near to A. maia Imbach, A. miharensis Nagata and A. naikaiensis Nagata. However, the new species is easily distinguished from the above mentioned species, by the structure of antenna 1,2 the shape of the lateral expansion of the pereopod 7 basis and the dactylus. From 
A. miharaensis, the new species is different by the setae peduncle of antenna 1,2 , the basis lateral expansion of pereopod 7 shorter and narrower, dactylus longer than propodus. From A. maia, described from Vietnam by Imbach (1967), A. dongnamensis is separated by the difference in the position of eyes in cephalon, the basis lateral expansion, the dactylus of pereopod 7, the antennae and the mandibular palps. Ampelisca naikaiensis is distinguished from the new species particularly by the pereopod 7 basis lateral expansion more round in form, the long ischium but short dactylus, uropod ramus more narrow and longer than peduncle. It may be that the four species in comparison above fit within a group of similar species of Ampelisca - the dongnamensis group, distributed in western South China Sea region.

Ampelisca talus sp. n. (Figs. 26-43)

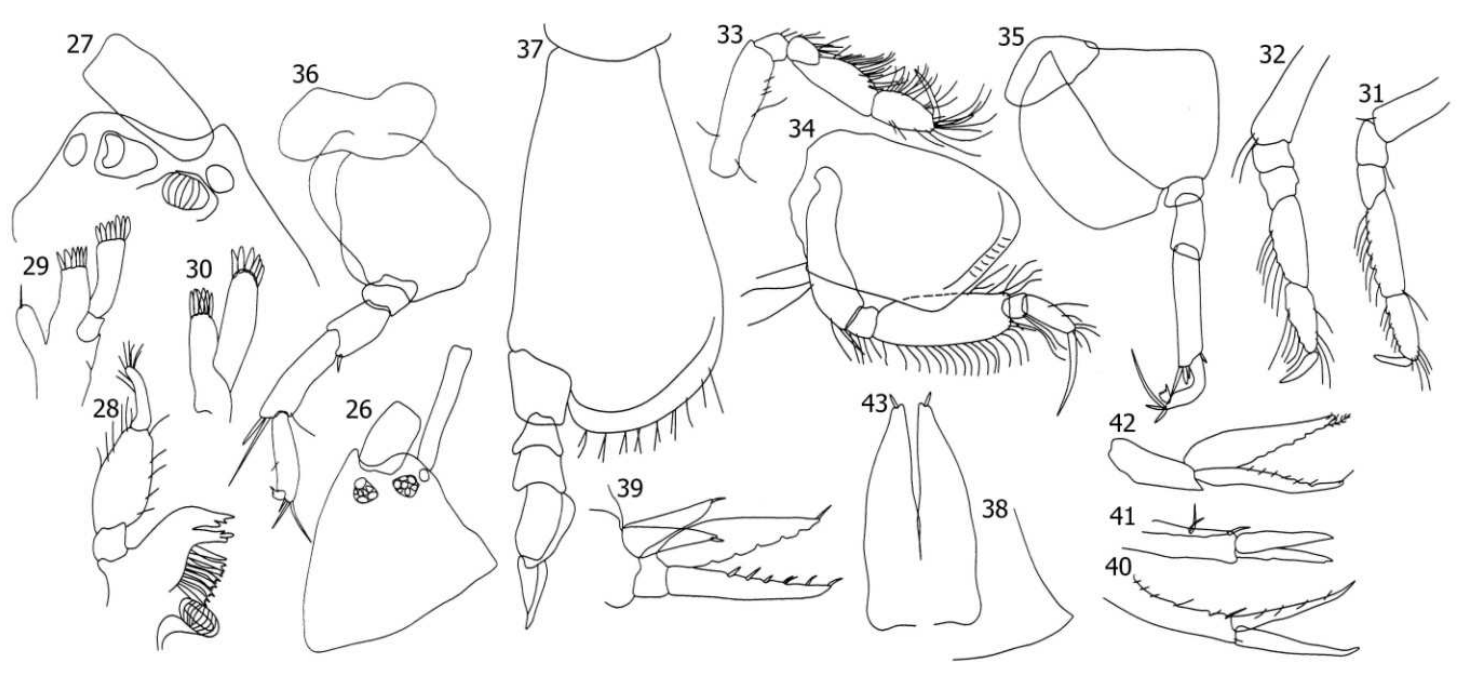

Figure 26-43. Ampelisca talus sp. n.

26-27. Head; 28. Mandible; 29-30. Maxilla 1-2; 31-32. Gnathopod 1-2; 33-36. Pereopod 3-6; 37. Pereopod 7; 38. Epimera 3; 39. Urosomit; 40-42. Uropod 1-3; 43. Telson.

Type material: Holotype female, $5.9 \mathrm{~mm}$, IEBR/CA H 0013, Vung Tau $\left(10^{\circ} 09.52^{\prime} \mathrm{N}\right.$, $\left.107^{\circ} 13.27^{\prime} \mathrm{E}\right), \quad 27$ May 2008. Paratypes: IEBR/CA P0013_2 (2 females, 5.7-5.9 mm), Vung Tau $\left(10^{\circ} 09.52^{\prime} \mathrm{N}, 107^{\circ} 13.27^{\prime} \mathrm{E}\right), 27$ May 2008. Vung Tau $\left(10^{\circ} 12.31^{\prime} \mathrm{N}, 105^{\circ} 29.71^{\prime} \mathrm{E}\right)$ IEBR/CA P0013_1, (1 females, $5.7 \mathrm{~mm})$ August 2000.

Type locality: Vung Tau (south-eastern area of Vietnam Sea)

Etymology: Name owing to the talus shape of the pereopod 7 propodus of the new species.

Description: Female, $5.9 \mathrm{~mm}$.

Head: Head with distal margin slightly concave; two eyes pairs with distinct lenses and
2 additional pigmented areas. Antenna 1 and antenna 2 nearly equal in length, reaching to midpoint of the body length. Antenna 1 peduncular article 1 robust, as long as half length of article 2, article 3 short; flagellum 18articulated. Antenna 2 with peduncular article 4 shorter than article $5(2 / 3 \mathrm{x})$; flagellum 20articulated. Mandibular palp with 3 articles, article 2 strongly inflated, article 3 finger form, shorter than article 2.

Pereon: Gnathopod 1 and gnathopod 2 normal form, carpus and propodus with densely setae on posteroventral margin. Pereopod 3 with coxa rectangular, basis and merus long, with scattered setae. Pereopod 4 coxa subquadrangular, with a tooth on posteroventral 
margin; basis and merus long and with densely setae. Pereopod 5 and pereopod 6 similar in form, round basis with scattered setae, and an abnormal curve-produced propodus in pereopod 5. Pereopod 7 with lateral basis expansion elongate, distal margin oblique with row of setae, slightly reaching distal end of ischium; article 3 quadrangular, equal in length with 2 next articles combined; article 4 and 5 similar in length, posterodistal corners produced; propodus originally talus shaped, as long as two previous articles combined in length; dactylus shorter than propodus, tapering distally.

Pleon: Epimera 3 with posteroventral corner sharp, but without teeth. Urosomite 1$2+3$ with tubercles on dorsal margin. Uropod 1 with ramus slightly shorter than peduncle, without setae, but with row of small spines on lateral margin of peduncle. Uropod 3 with ramus longer than peduncle; outer ramus with serrate lateral margin, distally setose. Telson narrowly lanceolate.

\section{Male: Unknown.}

Habitat: Soft bottom, 40-50 m, mud-sandy sediment.

Distribution: Vung Tau (south-eastern area of Vietnam Sea).

Remarks: Ampelisca talus sp. n. is distinctly separated from all known species in the region particularly by the unique talus shape of pereopod 7 propodus. From the similar species Ampelisca chinensis Imbach, described from Vietnam, the new species can be easily distinguished also by the long antenna 1, equal in length with antenna 2 , by the structure of uropod 3 with serrate margin of outer ramus, by the tooth armed coxa 4 of pereopod 4 and by the abnormally curved propodus of pereopod 5 .

Ampelisca thaoae sp. n. (Figs. 44-68)

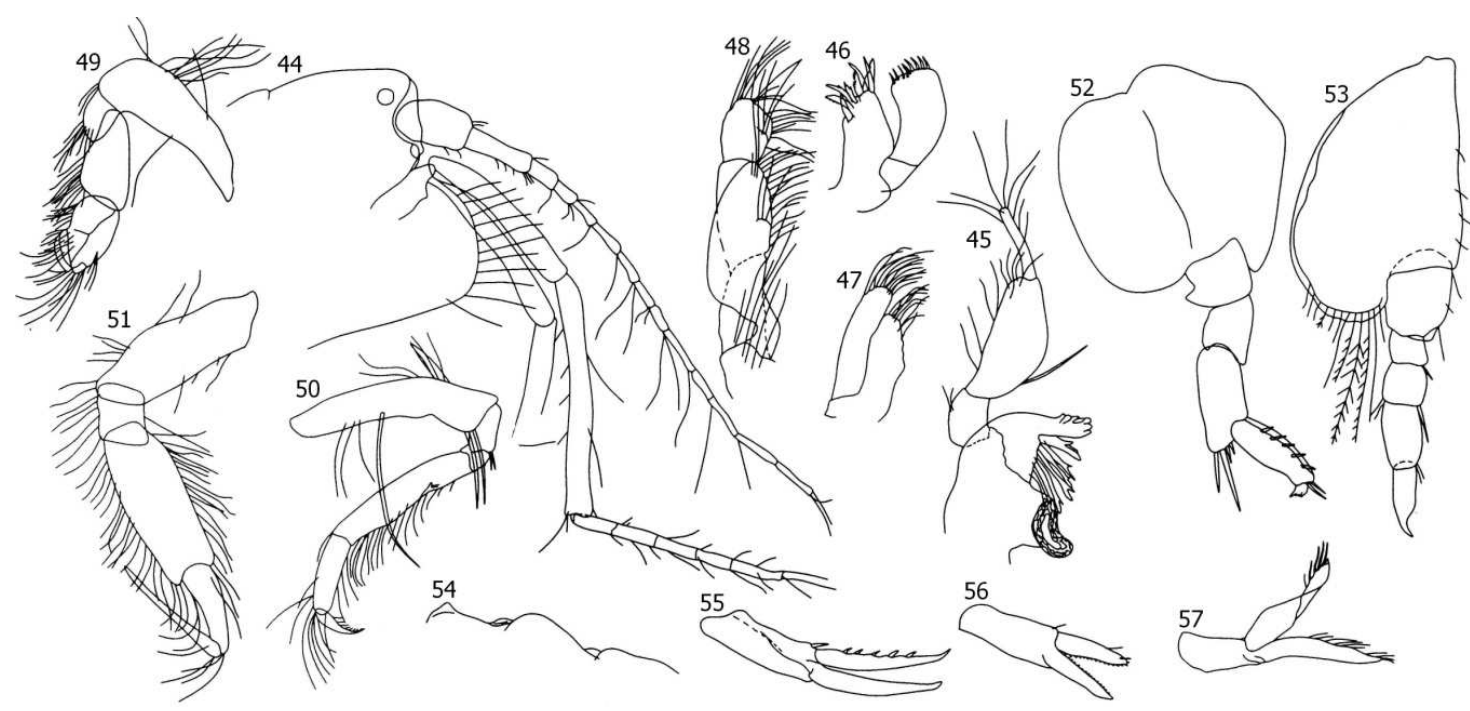

Figure 44-57. Ampelissca thaoae sp. n. (female)

44. Head; 45. Mandible; 46-47. Maxilla 1-2; 48. Maxilliped; 49-50. Gnathopod 1-2; 51-52. Pereopod 3, 6; 53. Pereopod 7; 54. Urosomit; 55-57. Uropod 1-3.

Type material: Holotype female, $6.2 \mathrm{~mm}$, IEBR/CA H0014, Vung Tau $\left(10^{\circ} 08.54\right.$ ' $\mathrm{N}$, $\left.107^{\circ} 14.09^{\prime} \mathrm{E}\right)$ August 2000. Paratype: IEBR/CA P0014_5 (5 females) Vung Tau (same station data and $\left.10^{\circ} 08.15^{\prime} \mathrm{N}, 107^{\circ} 14.67^{\prime} \mathrm{E}\right)$, May 2008 .
Type locality: Vung Tau, south-eastern area Vietnam Sea).

Etymology: Name of Dr. Thao, H.M., donator of amphipod materials using in this study. 
Description: Female, $6.5 \mathrm{~mm}$.

Head: Head with distal margin straight; tow eyes pairs in form distinct lenses. Antenna 1 over-reaching antenna 2 peduncle; peduncular article 1 robust, equal in length to article 2, article 3 short, flagellum 12-segmented. Antenna 2 reaching beyond of body end, peduncular article 4 shorter than article 5; flagellum 25-articulated Antennal sides armed with row of long setae. Mandibular palp with 3 articles, article 2 strongly swollen, article 3 shorter than article 2, finger like with long setae at distal end.

Pereon: Gnathopod 1 with short but broad carpus and propodus, with densely setae. Gnathopod 2 with slender carpus and propodus, long marginal setae. Pereopod 4 with quadrangular coxa, long and robust carpus and very long claw-like dactylus, longer than propodus, densely setose at sides. Pereopod 5 and pereopod 6 similar in form, with round basis, carpus and propodus cylindrical with rudimentary dactylus. Pereopod 7 with large basis lateral expansion, nearly semicircular, distal margin reaching to distal end of ischium, armed with a row of plumose setae; ischium large, squarish, as long as merus and carpus combined in length; merus with produced posterior corner, equal in length to carpus; propodus rectangular, as long as two previous articles combined in length; dactylus equal in length to propodus, tapering distally.

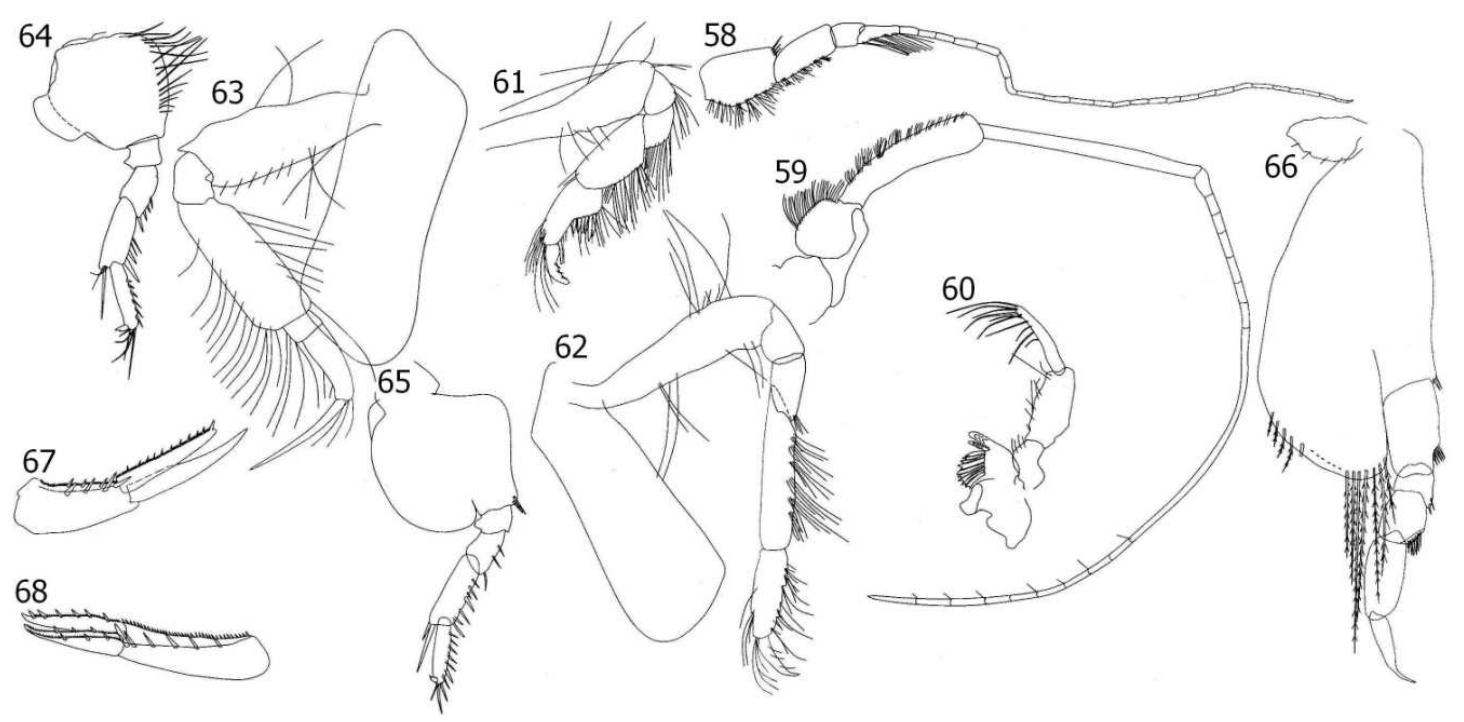

Figure 58-68. Ampelissca thaoae sp. n. (male)

58-59. Antenna 1-2; 60. Mandible; 61-62. Gnathopod 1-2; 63-65. Pereopod 4-6; 66. Pereopod 7; 67-68. Uropod 1-2.

Pleon: Urosomite $1-2+3$ with process on dorsal margin. Uropod 1 with ramus longer than peduncle, ramus shorter than peduncle. Uropod 3 with ramus narrow lanceolate longer than peduncle, densely setose. Telson long, narrowly lanceolate.

Male: Sexual dimorphic characters: Antenna 1 long, overreaching $1 / 2$ length of antenna 2; Antenna 2 reachig to the end of body length, peduncular articles Antenna 1 and antenna 2 armed with rows of short and rigid setae.

Habitat: Soft bottom, 40-50 m, coarse sediment, mud-sandy.

Remarks: The newly described Ampelisca thaoae sp. n. can be easily distinguished from other known species in the region by the equal length of peduncular articles 1 and 2 of antenna 1 , as they are frequently unequal in length in 
Ampelisca species, except in case of Ampelisca honmungensis Imbach, described from Vietnam also, but with another type locality (Hon Mun Nha Trang). However, A. honmungensis can be distinguished from the new species, by the presence of a unique process on the antenna 1 peduncular first article, the short antenna 1 and antenna 2, the unswollen mandibular palp article 2, and by the structures of pereopod 7 and uropod 3. From Ampelisca zamboangae the new species can be separated by the equal length of the two peduncular articles 1 and 2 of antenna, the long antenna, and other characters. This newly described species is near to Ampelisca ceratophoculata Ren, described from China, with a similar pereopod 7 and a swollen mandibular palp, but clearly distinguished from the chinese species by the structure of antenna 1 and antenna 2 .

Ampelisa submisakiensis sp. n. (Figs. 69-86)

Type material: Holotype female, $5.5 \mathrm{~mm}$, IEBR/CA H0015, Vung Tau $\left(10^{0} 07.32 ' \mathrm{~N}\right.$, $\left.107^{0} 13.19^{\prime} \mathrm{E}\right), 22-25$ May 2008. Paratype: IEBR/CA P0015_4 (4 females, 5.5-5.7 mm), Vung Tau, May 2008.

Type locality: Vung Tau, south-eastern area of the Vietnam Sea.

Etymology: The new species is near to Ampelisca misakiensis Dahl in taxonomy characters.

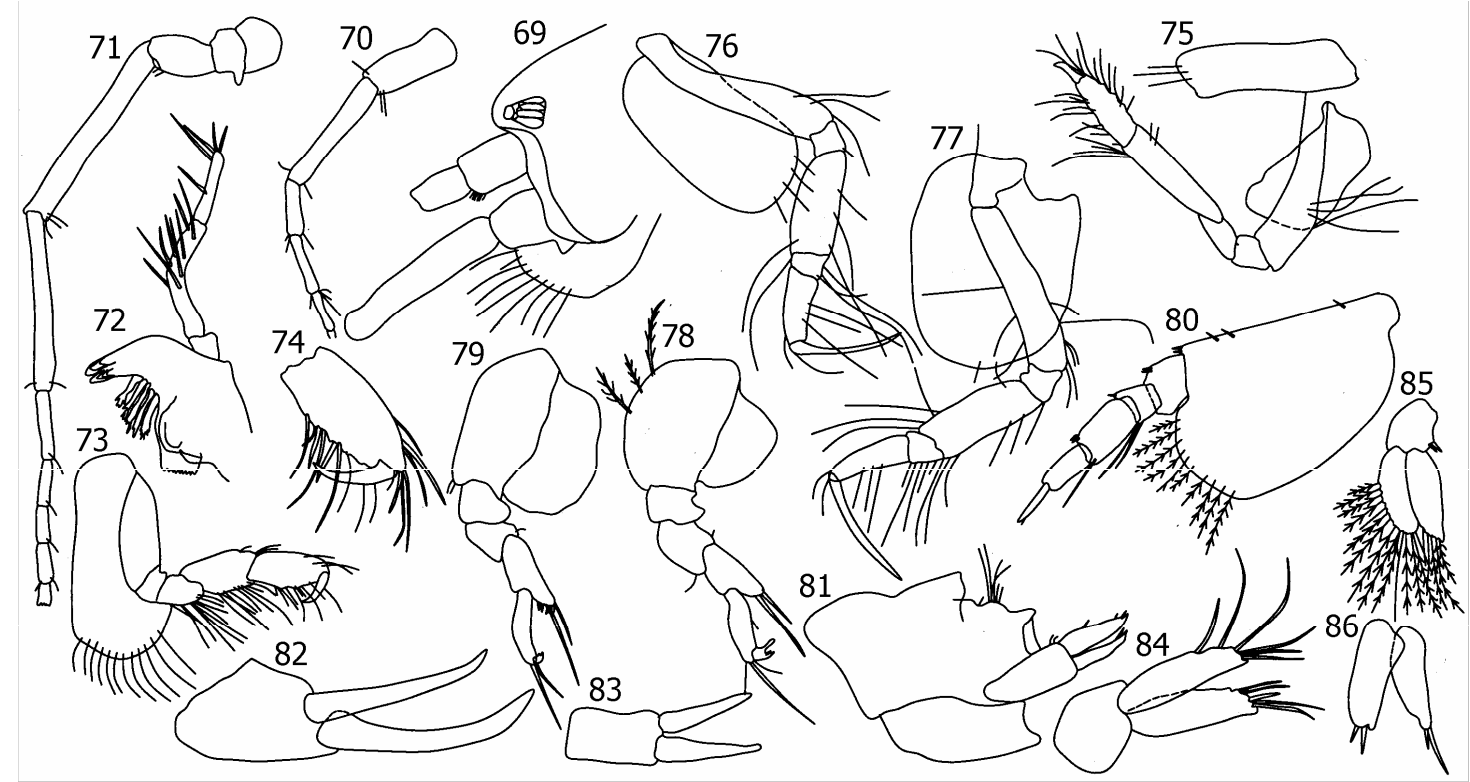

Figure 69-86. Ampelisca submisakiensis sp. n.

69. Head; 70-71. Antenna 1-2 ; 72. Mandible; 73-74. Gnathopod 1; 75. Gnathopod 2; 76-80. Pereopod 3-7 ; 81. Urosomit; 82-83. Uropod 1, 2; 84-85. Uropod 3; 86. Telson.

Description: Female, $5.5 \mathrm{~mm}$.

Head: Head with produced anterodistal corner, distal margin straight; eyes two pairs in form of distinct lenses, but not clearly visible. Antenna 1 short not reaching distal end of antenna 2 peduncle; article 1 slightly longer than article 2, article 3 short, flagellum 8articulated Antenna 2 long, reaching to end of body length, article 4 slightly longer than article 5, flagellum 20-articulated Antennae articles naked, not setose. Mandibular palp 3 with 3 articles, with article 2 longer than article 3, curve at the middle portion, densely setose in distal part. Article 3 straight, setose.

Pereon: Gnathopod 1 with coxa short, broad, distally rounded, carpus and propodus 
equal in length. Gnathopod 2 with coxa 4 narrow, rectangular, carpus and propodus long, narrow, distal part setose. Pereopod 3 and pereopod 4 similar in form, with coxa quadrangular, merus, propodus scattered setose, dactylus very long, as 2 times in length of propodus. Pereopod 5 and pereopod 6, with round coxa, carpus strongly produced in posterior corners, dactylus rudimentary with serrate appendices; carpus and propodus with distal long setae. Pereopod 7 with large basis lateral expansion, semicircular, with row of plumose setae in distal margin, not reaching distal end of ischium; ischium large, squarish; merus short with produced posterior corners; carpus oval, nearly as long as ischium; propodus narrower than previous article, equal in length to carpus; dactylus nearly equal in length to propodus, slender, ending in a point.

Pleon: Urosomite 1-2+3 with process on dorsal margin. Uropod 1 with ramus unequal in length, longer than peduncle. Uropod 2 with ramus similar in length with peduncle, with marginal spines. Uropod 3 with ramus broad and longer than peduncle, distal end armed with long setae.

\section{Male: Unknown.}

Habitat: Soft bottom, 40-50 m, muddy-sand sediment.

Distribution: Vung Tau (south-eastern part, Vietnam Sea).

Remarks: The new species Ampelisca submisakiensis sp. $\mathrm{n}$. is quite near to the known species Ampelisca misakiensis Dahl, which also occurs in the Vietnam Sea, by the length of antennae, the structure of pereopod 5 and pereopod 6, uropod 3 and the armature on dorsal margin of urosomite 1 and $2+3$. However, in details, the new species can be distinguished from A. misakiensis by many different characters:

Head less produced in anterodistal margin, eyes two pairs (in A. misakiensis eyes one pair).

Antenna 1 with article 1 and 2 equal in length. (in A. misakiensis not equal in length).

Mandibular palps with segment 2 distinctly curve at middle portion and longer than segment 3 (in A. misakiensis, segment 2 straight and shorter than segment 3).

Pereopod 7 with large basis lateral expansion reaching to beyond of ischium with row of plumose setae in distal margin. Proportion between pereopod 7 articles quite different from A. misakiensis.

It may be, the 4 species A. misakiensis, A. miharaensis, A. submisakiensis and A. taynamensis fit within near species group misakienis, distributed in western South China Sea region.

\section{Genus Byblis Boeck, 1871}

Byblis caecus sp. n. (Figs 87-104)

Type material: Holotype female, $5.2 \mathrm{~mm}$, IEBR/CA H0016, Kien Giang $\left(10^{\circ} 0.12 ' \mathrm{~N}\right.$, $\left.104^{\circ} 30.56^{\prime} \mathrm{E}\right), 15$ September 2007.

Paratype: IEBR/CA P0016_2 (2 females, Kien Giang, same station data) 10 September 2007.

Type locality: Kien Giang, south-western area of Vietnam Sea (eastern area of the Gulf of Thailand).

Etymology: Eyes are not present in the new species.

Description: Female, $5.2 \mathrm{~mm}$.

Head: Head nearly as long as first three peraeon segments combined in length; anterodistal margin with interantennal lobe; no eyes present. Antenna 1 overreaching peduncle, to middle antenna 2 length; Antenna 1 article 1 shorter than article 2, article 3 as half length article 2; flagellum 9-segmented. Antenna 2 with article 4 slightly shorter than article 5; flagellum 18-segmented reaching to middle body length with marginal long setae. Mandibular palps with segment 2 and 3 similar in length, not inflated, with spiral row of hooks in distal part.

Pereon: Gnathopod 1 with propodus shorter than carpus; dactylus claw like, serrate. Gnathopod 2 similar in shape with gnathopod 1. Pereopod 5 and pereopod 6 with carpus slightly 
produced in posterior corners, with long setae. Pereopod 7 with long lateral basis expansion, semilunar in form, reaching to distal end of carpus; distal margin oblique with row of dense plumose setae; carpus subrectangular, longer than previous article, outer margin setose; propodus finger form, slightly shorter than carpus; dactylus short, slender, with long terminal seta.
Pleon: Urosomite 1-3 with smooth dorsa margin. Uropod 1 with naked ramus, longer than peduncle. Uropod 2 with ramus equal in length with peduncle, with marginal row of spines. Uropod 3 with ramus longer than peduncle, inner margin multiserrate. Telson cleft slightly less than half of its length.

Male: Unknown.

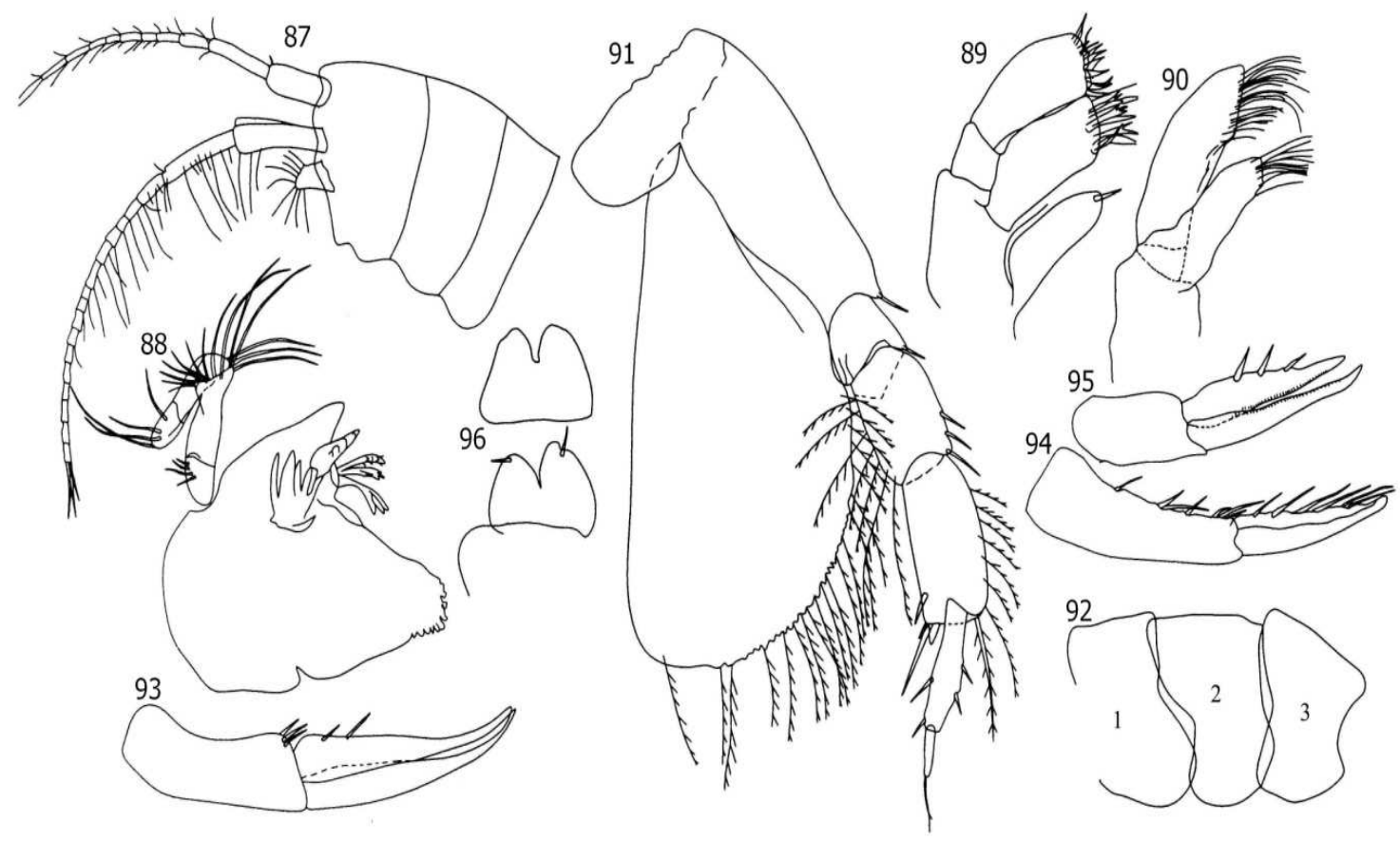

Figure 87-96. Byblis caecus sp. n. (female)

87. Head; 88. Mandible; 89-90. Maxilla 1-2; 91. Pereopod 7;

92. Epimera 1-3; 93-95. Uropod 1-3; 96. Telson.

Habitat: Soft bottom, 5-10 m, mud-sandy sediment.

Distribution: Kien Giang, south-western area of Vietnam sea (Gulf of Thailand).

Remarks: Byblis caecus sp. $\mathrm{n}$. is easily separated from all known species in Vietnam Sea $[6,8]$ by the absence of eyes and pigmented areas in this new species. Besides, difference revealed also in other characters, as structure of antennae, pereopod 7 of this species in comparison with all known species. From 2 species newly described from China - Byblis bandasetus Ren, and Byblis typhlotes Ren (Ren, 2002), similar by the absence of eyes, the new described species from Vietnam can be distinguished by the different structure of antennae and particularly of pereopod 7 of the Vietnamese specimen. 


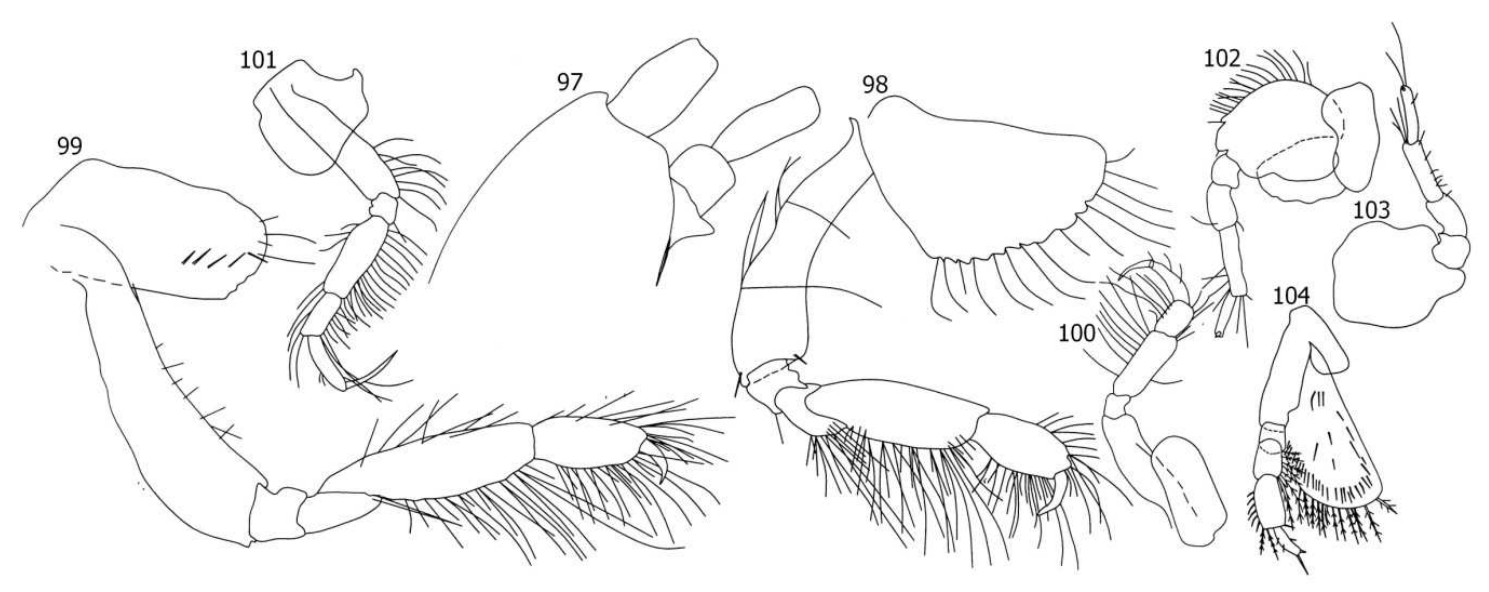

Figure 97-104. Byblis caecus sp. n. (female)

97. Head; 98-99. Gnathopod 1-2; 100-103. Pereopod 3-6; 104. Pereopod 7.

Table 1. List of Ampeliscidae species found in nearshore waters of Vietnam at present times

\begin{tabular}{|c|c|c|c|}
\hline $\mathrm{N}^{0}$ & Species & $\begin{array}{c}\text { Previously recorded } \\
\text { species }[1,2,6,7,8,9 \text {, } \\
12]\end{array}$ & $\begin{array}{c}\text { Newly recorded } \\
\text { species [12] }\end{array}$ \\
\hline & Family Ampeliscidae Costa, 1857 & & \\
\hline & Genus Ampelisca Kroyer, 1842 & & \\
\hline 1 & Ampelisca alatopedunculata Ren, 2006 & & $\mathrm{X}$ \\
\hline 2 & Ampelisca bocki Dahl, 1945 & $\mathrm{X}$ & \\
\hline 3 & Ampelisca brevicornis (Costa, 1853) & $\mathrm{X}$ & \\
\hline 4 & Ampelisca chinensis Imbach, 1967 & $\mathrm{X}$ & \\
\hline 5 & Ampelisca cyclops Walker, 1904 & $\mathrm{X}$ & \\
\hline 6 & Ampelisca dongnamensis sp. $\mathrm{n}$. & & \\
\hline 7 & Ampelisca furcigera Bulycheva, 1936 & $\mathrm{X}$ & \\
\hline 8 & Ampelisca honmungensis Imbach, 1967 & $\mathrm{X}$ & \\
\hline 9 & Ampelisca iyoensis Nagata, 1959 & $\mathrm{X}$ & \\
\hline 10 & Ampelisca maia Imbach, 1967 & $\mathrm{X}$ & \\
\hline 11 & Ampelisca miops K.H. Barnard, 1916 & $\mathrm{X}$ & \\
\hline 12 & Ampelisca miharaensis Nagata, 1959 & $\mathrm{X}$ & \\
\hline 13 & Ampelisca misakiensis Dahl, 1944 & $\mathrm{X}$ & \\
\hline 14 & Ampelisca naikaiensis Nagata, 1959 & $\mathrm{X}$ & \\
\hline 15 & Ampelisca pygmaea Schellenberg, 1938 & & $\mathrm{X}$ \\
\hline 16 & Ampelisca stenopa Schellenberg, 1925 & $\mathrm{X}$ & \\
\hline 17 & Ampelisca submisakiensis sp. $\mathrm{n}$. & & \\
\hline 18 & Ampelisca talus sp. $\mathrm{n}$. & & \\
\hline 19 & Ampelisca taynamensis sp. $\mathrm{n}$. & & \\
\hline 20 & Ampelisca thaoae sp. $\mathrm{n}$. & & \\
\hline 21 & Ampelisca typlota Ren, 2006 & & $\mathrm{X}$ \\
\hline \multirow[t]{2}{*}{22} & Ampelisca zamboangae Stebbing, 1888 & & $\mathrm{X}$ \\
\hline & Genus Byblis Boeck, 1871 & & \\
\hline 23 & Byblis brachyura Margulis, 1968 & $\mathrm{X}$ & \\
\hline
\end{tabular}




\begin{tabular}{|c|c|c|c|}
\hline 24 & Byblis calisto Imbach, 1967 & $\mathrm{X}$ & \\
\hline 25 & Byblis caecus sp. n. & & \\
\hline 26 & Byblis io Imbach, 1967 & $\mathrm{X}$ & \\
\hline 27 & Byblis febris Imbach, 1967 & $\mathrm{X}$ & \\
\hline 28 & Byblis kallarthra Stebling, 1886 & $\mathrm{X}$ & \\
\hline 29 & Byblis mисronata Pirlot, 1936 & $\mathrm{X}$ & \\
\hline 30 & Byblis pilosa Imbach, 1967 & $\mathrm{X}$ & \\
\hline 31 & Byblis pirloti Margulis, 1968 & $\mathrm{X}$ & \\
\hline 32 & Byblis plumosa Margulis, 1968 & $\mathrm{X}$ & \\
\hline 33 & Byblis rhinoceros Pirlot, 1936 & $\mathrm{X}$ & \\
\hline 34 & Byblis serrata Smith, 1873 & $\mathrm{X}$ & \\
\hline 35 & Byblis verae Margulis, 1968 & $\mathrm{X}$ & \\
\hline & Total & 25 & 4 \\
\hline
\end{tabular}

Acknowledgements: The authors would like to expess many thanks to Dr. Jim Lowry for reading and correction the manuscript. We also would like to present our gratitude to the following persons and institutions for offering us the materials: Dr. Hoang Minh Thao Biological Department, R\&D Center for Petroleum Safety \& Environment; Dr. Do Cong Thung - Instute of Marine Resources and Environment Hai Phong; Dr. Dao Tan Ho Institute of Oceanography Nha Trang and to NAFOSTED-106.12.29.09; ĐTĐL.2011-G/23; VAST for funding the field work.

\section{REFERENCES}

1. Le Hung Anh, Dang Ngoc Thanh, 2010. Ampeliscid crustaceans ampeliscidae (Amphipoda - Gammaridae) from nearshore waters of Vietnam. TAP CHI SINH HOC, 32(4): 40-44.

2. Barnard J. L., Karaman G. S., 1991. The Families and Genera of marine Gammaridean Amphipoda (Except marine gammaroids). Part. 1. Records of the Australian Museum, Supplement, 13: 84-91.

3. Chilton M. A., 1921. Amphipoda. Fauna of the Chilka lake. Memoirs of the Indian Museum, V: 521-558.

4. Dang N. T., 1968. Nouveaux amphipodes des eaux douces et saumatres du Nord Vietnam. Zoologicheski Juropodnal, XLVII(2): 212-221 (in Russian).
5. Hirayama A., 1991. Marine Ampeliscidae (Crustacea Amphipoda) from Hong Kong Asian Mar. Biol., 8: 77-93.

6. Imbach M. C., 1967. Gammaridean Amphipoda from the South China Sea. NAGA Report, 4(1): 40-167.

7. Lowry J. K., 2000. Taxonomic status Amphipoda Crustaceans in the South China Sea with a checklist of known species. The Raffles Museum Bulletin of Zoology. Suropodpl., 8: 300-342.

8. Margulis R. J., 1968. Ampeliscidae (Amphipoda: Gammaridea) in the North Western part of the South China Sea. Zoologicheskii Zhurnal, 47: 1479-1488, 4 figs.

9. Nagata K., 1965. Studies on marine Gammaridean Amphipoda of the Seto Inland Sea. I-IV. Publications of the Seto Marine Biological Laboratory, 13(2/5): 131348.

10. Pirlot J. M., 1935. Les Amphipodes de l'Expedition du Siboga. 2. Les Amphipodes Gammarides II., 3. Les Amphipodes littoreaux. III(1). Siboga Exp. 33e: ,277292.

11. Rabindranath P., 1975. Marine Gammaridea (Crustacea Amphipoda) from the Indian Region, Family Ampeliscidae. Hydrobiologia, 46(2-3): 241-262.

12. Ren X. Q., 2006. Fauna Sinica. Invertebrate. 
Crustacea Amphipoda Gammaridea (I) Ampeliscidae, 41: 88-198.

13. Đặng Ngọc Thanh, 1965. Một số loài giáp xác mới tìm thấy trong nước ngọt và nước lợ miền bắc Việt Nam. Tập San Sinh vật Địa học, 4(3): 146-152.

14. Đặng Ngọc Thanh, 1967. Các loài mới và giống mới tìm thấy trong khu hệ động vật Không xương sống nước ngọt và nước lợ miền bắc Việt Nam. Tập san Sinh vật
Địa học, 4(3-4): 155-164.

15. Dang Ngoc Thanh, Le Hung Anh, 2005. New data on the Gammaridean Amphipoda species composition of the Vietnam nearshore waters. TAP CHI SINH HOC, 27(2): 1-7.

16. Dang Ngoc Thanh, Le Hung Anh, 2012. New Amphipoda Crustaceans species recently found in Vietnam nearshore waters. TAP CHI SINH HOC, 34(2): 145-157.

\title{
HO GIÁP XÁC CHÂN KHÁC AMPELISCIDAE (AMPHIPODA: GAMMARIDEA: AMPELISCIDAE) CỦA BIỂN VIẸT NAM
}

\author{
Đặng Ngọc Thanh, Lê Hùng Anh
}

Viện Sinh thái và Tài nguyên sinh vật, Viện Hàn lâm KH \& CN Việt Nam

\section{TÓM TÁ̀T}

Bài báo đưa ra danh sách 35 loài thuộc họ Ampeliscidae, trong đó, mô tả 6 loài mới thuộc các giống Ampelisca và Byblis đó là (Ampelisca taynamensis sp. n., A. dongnamensis sp. n., A. talus sp. n., A. thaoae sp. n., A. submisakiensis sp. n., Byblis caecus sp. n.). Những loài này được tìm thấy ở vùng biển ven bờ Việt Nam (Bà Rịa Vũng Tàu, Cà Mau và Kiên Giang); tổng hợp ghi nhận 4 loài thuộc họ này có mặt ở Việt Nam trước đó đã nâng tổng số loài thuộc họ Ampeliscidae ở vùng biển ven bờ Việt Nam lên thành 35 loài.

Đặc điểm chẩn loại của 6 loài mới:

Ampelisca taynamensis sp. n.: Râu 1 dài bằng cuống Râu 2. Chân ngực 5 đốt 2 tròn với vết lõm lớn ở cạnh dưới. Chân ngực 7 có tấm bên đốt 2 hẹp dài, cạnh dưới xiên không vượt quá đốt 3 . Các đốt đuôi 1-2 cạnh lưng có mấu lồi lớn.

Ampelisca dongnamensis sp. n.: Râu 1 dài vượt quá cuống râu 2. Chân ngực 7 có tấm bên đốt 2 hẹp dài, vượt quá đốt 3 . Các đốt $3,4,5$ vuông góc, dài gần bằng nhau. Đốt 7 dài hơn đốt 6 , hình lá nhọn cong đầu. phình to.

Ampelisca talus: Râu 1 xấp xỉ dài bằng Râu 2, Chân ngực 7 có đốt 6 hình gót chân, pan hàm trên có đốt 2

Ampelisca thaoae sp. n.: Râu 1 dài vượt quá cuống Râu 2, râu 2 dài vượt quá thân. Chân ngực 7 có tấm bên đốt 2 hình bán nguyệt, cạnh dưới tròn, không vượt quá đốt 3 . Đốt 2 hình lưỡi dao nhọn đầu, dài bằng đốt 6.

Ampelisca submisakiensis sp. n.: Râu 1 ngắn, râu 2. Pan hàm trên có đốt 2 dài gãy khúc, dài hơn đốt 3 . Chân ngực 7 tấm bên đốt 2 lớn, hình bán nguyệt, cạnh dưới tròn, không vượt quá đốt 3 .

Byblis caecus sp. n.: Không có mắt. Râu 1 dài tới giữa râu 2. Chân ngực 7 có tấm bên đốt 2 hình bán nguyệt, cạnh dưới dài tới ngọn đốt 5 .

Tù khóa: Ampeliscidae, phân loại học, loài mới cho khoa học, Việt Nam.

Ngày nhận bài: 9-7-2012 